\title{
Verdier i formålsparagraf og minne- materialet etter 22. juli 2011
}

Av Sidsel Lied og Ingebjørg Stub

\begin{abstract}
Many of the texts and drawings from spontaneous memorial places in the Oslo area in the days after the bombing of government buildings and the shooting and killing of young people on Utøya island on July $22^{\text {nd }} 2011$, are made by children.' The main focus of this article is what values these memorial utterances show that children considered important and worth fighting for in the aftermath of this event. Love and togetherness, life and human worth were often in focus in these utterances - utterances that are closely related to central values in the objects clause («formålsparagrafen») of the Norwegian Education Act, such as love for one's neighbour, respect for human worth, diversity and solidarity. But children's memorial utterances also indicate that the very fight for these values sometimes puts the same values under pressure: in some texts and drawings the terrorist is dehumanised and deprived of his human worth. The article gives examples of and discusses these phenomena. The theoretical perspective used in the article is Gunther Kress and Theo van Leeuwen's grammar of western visual design.
\end{abstract}

Keywords: Values, 22. July 2011, children's values, values in Norwegian school, grammar of visual design

SidSEL LieD (f. 1948), Ph.D, prof. emerita i religionsdidaktikk ved Høgskolen i Hedmark. E-post: sidsel.lied@hihm.no INGEBJøRG STUB $\emptyset$ (f. 1951), førsteamanuensis i RLE ved Høgskolen i Hedmark. E-post: ingebjorg.stubo@hihm.no Adresse: Høgskolen i Hedmark, postboks 40o, 2418 Elverum

Hvis du ønsker ă vite noe om viktige riter, trosforestillinger og moralske retningslinjer i et samfunn, så skal du iaktta dette samfunnet når det er under press. For når en er under press - f.eks. når det som blir betraktet som »normale forhold» av en eller annen grunn blir satt på vent - blir det implisitte eksplisitt, og det uuttalte og instinktivekommer tiloverflaten, sier sosiologiprofessor Grace Davie (Davie, 2007). Tiden etter 22. juli 2011 var en slik tid for det norske samfunnet: Det som i norsk

1 Den 22. juli 2011 bombet Anders B. Breivik bygninger i regjeringskvartalet i Oslo. Åtte mennesker ble drept og mange skadd. Noen timer senere samme dag skjøt og drepte Breivik 69 ungdommer som deltok på Arbeiderpartiets sommerleir på Utøya. Enda flere ble såret. I dagene etter ble det tent lys og lagt ned roser og hilsener fra barn, ungdommer og voksne i form av tekster og tegninger på spontane minnesteder. Riksarkivet i Norge samlet inn, tok vare på og digitaliserte 25000 dokumenter fra de spontane minnestedene i Oslo og Utvika i tiden etter terrorhandlingene (Norli \& Gausdal, 2013). Slik ble de gjort tilgjengelige for forskning. Det er tekster og tegninger fra dette digitaliserte materialet fra disse minnestedene vi i denne artikkelen kaller «minnematerialet». Inneværende nummer av Prismet inneholder tre artikler som alle handler om dette materialet. Denne første artikkelen undersøker hvilke verdier som kommer til uttrykk i de aktuelle tekstene og tegningene, og viser at dette er verdier som i stor grad faller sammen med verdier i skolens formålsparagraf. Den gir bakgrunn for de to følgende artiklene, «Arbeid med verdier i skolen: På jakt etter verdier i minnematerialet etter 22. juli 2011» av Lied og Kveset, og «Dialoger om verdier i grunnskolens formålsparagraf - med minnematerialet fra 22.juli som læremiddel» av Stubø og Markeng, som begge gir eksempler på hvordan minnematerialet kan være et egnet læremiddel når læreren skal arbeide med verdier som formålsparagrafen framhever skal være sentrale i norsk skole. Siden de tre artiklene henger sammen, vil det forekomme noen gjentakelser, samtidig som hver artikkel løfter fram forskjellige hovedperspektiver. Artiklene kan leses både som en helhet og hver for seg. 
sammenheng blir sett på som «normale forhold», ble satt til side etter de alvorlige terrorhandlingene i regjeringskvartalet og på Utøya. Tiden var i stedet preget av rosetog og minnesamlinger på gater og torg over hele landet, og på spontane minnesteder ble det tent lys og lagt ned roser og hilsener fra barn, ungdommer og voksne i form av tekster og tegninger som inneholdt trøsteord, verdiutsagn, bønner og uttrykk for sorg, sjokk og sinne (Aagedal, Botvar, \& Høeg, 2013; Lied \& Lödén, 2014; Lied \& Undseth Bakke, 2013; Stormark, 2011). Denne artikkelen kartlegger og drøfter hvilke verdier barn uttrykte på et tidspunkt da det norske samfunnet var under press, og forholdet mellom disse verdiene og verdiene i skolens formålsparagraf.

\section{FormÅlsparagraf, Verdier og MINNEMATERIALE}

Den nåværende formålsparagrafen for norsk grunnskole og videregående opplæring ble vedtatt i Stortinget i desember 2008 og trådte i kraft i januar 2009. I denne paragrafen, som er en del av opplæringsloven, fastsetter norske myndigheter et bestemt verdigrunnlag for opplæringen, bl.a. gjennom å liste opp verdier som opplæringen skal bygge på. Den lyder slik:

\section{Formålet med opplceringa}

Opplaringa $i$ skole og larebedrift skal, $i$ samarbeid og forståing med heimen, opne dører mot verda og framtida og gi elevane og larlingane historisk og kulturell innsikt og forankring.

Opplaringa skal byggje på grunnleggjande verdiar $i$ kristen og humanistisk arv og tradisjon, slik som respekt for menneskeverdet og naturen, på åndsfridom, nestekjœrleik, tilgjeving, likeverd og solidaritet, verdiar som òg kjem til uttrykk $i$ ulike religionar og livssyn og som er forankra i menneskerettane.

Opplæringa skal bidra til å utvide kjennskapen til og forståinga av den nasjonale kulturarven og vår felles internasjonale kulturtradisjon.

Opplaringa skal gi innsikt $i$ kulturelt mangfald og vise respekt for den einskilde si overtyding. Ho skal fremje demokrati, likestilling og vitskapleg tenkjemåte.

Elevane og lorlingane skal utvikle kunnskap, dugleik og holdningar for å kunne meistre liva sine og for å kunne delta $i$ arbeid og fellesskap i samfunnet. Dei skal få utfalde skaparglede, engasjement og utforskartrong. Elevane og larlingane skal læere å tenkje kritisk og handle etisk og miljøbevisst. Dei skal ha medansvar og rett til medverknad.

Skolen og larebedrifta skal møte elevane og lcrlingane med tillit, respekt og krav og gi dei utfordringar som fremjar danning og larelyst. Alle former for diskriminering skal motarbeidast.

(Kunnskapsdepartementet, 2008a, § 1-1)

Stortinget har gjennom denne opplistingen gitt skolen et bestemt verdifundament, og når det heter at «opplæringa skal byggje på» (vår utheving) visse grunnleggende verdier - som bl.a. menneskeverd, nestekjærlighet, likeverd og solidaritet - er det naturlig å tolke paragrafen slik at disse verdiene skal reflekteres i det daglige arbeidet. Formålsparagrafen har altså fått en normativ funksjon som avviser verdirelativisme og tanken om en verdinøytral skole (Bostad, 2008).

Da den nye formålsparagrafen ble lansert i 2008, framhevet regjeringen i en pressemelding at formålsparagrafen understreker at skolen skal formidle verdier (Kunnskapsdepartementet, 2008b). Begrepet verdiformidling kan gi assosia- 
sjoner i retning av at det er mulig med en enkel overføring av verdier fra voksne til barn. Det er imidlertid en forenkling, noe bl.a. den svenske religionsdidaktikeren Karin Sporre understreker når hun bruker uttrykket «value formation». Hun framhever at barn ikke er en tabula rasa som skolens voksne skal fylle med verdier, men betrakter både barn og voksne som bærere og formidlere av verdier (Sporre, 2012).

Kunnskapsutvikling, læring og identitetsdannelse - inkludert utvikling og internalisering av verdier og verdihierarki - er sosiale, situerte og kulturelle prosesser. Disse prosessene foregår i interaksjon mellom enkeltindividet og hans/hennes kontekster (Dysthe, 1997, 2001; Säljö, 2006; Vygotskij, 2001). Siden ethvert menneske er en integrert del av de sosiale og kulturelle kontekster det hører til innenfor, kan et individs verdier langt på veg sies å speile verdiene i de kontekstene det er en del av (Blackburn, 2001; Lied, 2012; Løken, 2012; Taylor, 1985). Med dette mener vi ikke å si at enhver innbygger alltid deler de verdiene som finnes i hans eller hennes sosiokulturelle kontekst. Men på grunn av den stadige interaksjonen mellom individ og kontekst vil ethvert menneske alltid være i interaksjon med de verdiene som er til stede i konteksten han/hun er en del av. Individet kan da akseptere, nyansere eller kritisere kontekstens verdier. På dette viset speiler de verdiene som individet er i dialog med, samfunnets verdier.

I minnematerialet etter 22. juli 2011 ser vi tydelig barn og unge i rollen som verdiformidlere. Lied har studert alle dokumenter fra Domkirkeplassen i Oslo og fra Utvika som Riksarkivet (se fotnote 1) har karakterisert som «hilsener/tegninger med og uten tekst».2 I denne artikkelen setter vi søkelyset på verdier som kommer til uttrykk i barns ytringer innenfor denne kategorien, og spør: Hva kan barns ytringer i minnematerialet fra Domkirkeplassen i Oslo og Utvika si om verdier barn fant det viktig a formidle i tiden etter 22. juli 2011? Ncermere bestemt: Hvilke verdier er til stede i disse ytringene, hvilke verdier står fram som viktige, og hvilke kan synes å vore under press?

Skolen er en viktig del av norske barns sosiale kontekst. Det kan derfor også være interessant å se om noen av de sentrale verdiene i skolens formålsparagraf kommer til uttrykk i minnematerialet. For å prøve å svare, vil vi gjøre følgende: Først vil vi presisere hva vi mener med begrepet verdier. Deretter presenterer vi sosialsemiotikerne Gunther Kress og Theo van Leeuwens grammatikk for vestlig design, og bruker deres grammatikk som analyseredskap når vi leter i tekster og tegninger etter verdier som barn løftet fram i tiden etter 22. juli. Ytringer som viser verdier som framheves som viktige å ta vare på, blir så presentert. Til slutt rettes oppmerksomheten mot ytringer som kan sies å peke på verdier som var truet eller under press i denne perioden.

\section{BEgREPER OG TEORETISK \\ PERSPEKTIV \\ Verdier}

Verdi er et sentralt begrep i denne artikkelen. Professor Ivar Asheim definerer en verdi som en bestemmelse av eller en betegnelse for noe som på en avgjørende måte konstituerer og gir utgangspunkt,

2 Lieds arbeid med minnematerialet er en del av prosjektet Kritiske hendelser, Verdier og Nasjonal identitet (KVN-prosjektet), som studerer det digitaliserte minnematerialet. De andre forskerne som deltar i prosjektet, er professor Geir Skeie, UiS og Stockholms universitet, professor Kerstin von Brömssen, Högskolan Väst, og dosent Hans Lödén, Karlstads universitet. $\mathrm{PhD}$-stipendiat Sidsel Undseth Bakke, UiS, er også tilknyttet prosjektet. 
rammer og mål for måter å leve sammen på i et samfunn (Asheim, 2005; Stubø, 2012). Professor Jan Kåre Hummelvoll understreker at verdier handler om hva som kan være godt eller ondt, rett eller galt, ønsket eller uønsket, prisverdig eller utilrådelig med hensyn til menneskelige behov, interesser, idealer eller handlinger (Hummelvoll, 2014). Begge disse innholdsbestemmelsene får fram at verdier er knyttet til menneskelige handlinger og dermed til etikk og moral. Men de får også fram at verdier er noe som peker utover det etiske og omhandler det som ofte kalles grunnleggende verdier eller verdier som har egenverdi. Eksempler på slike verdier er liv og helse. Innenfor kristen tenkning sies det at Gud er kjærlighet. Kjærlighet blir i en slik sammenheng eksempel på det den norske etikeren Lars Gunnar Lingås kaller immaterielle tilstander (Hansen \& Lingås, 2005), eller som også kan betegnes åndelige verdier.

Med utgangspunkt i filosofen Charles Taylor sier høgskolelektor Harald Løken at verdier som en person identifiserer seg med, viser hva som er viktig for denne personen og hva som står på spill for ham eller henne i en bestemt situasjon (Løken, 2012; Taylor, 1989). Når vi her spør etter hvilke verdier som står fram som viktige $\mathrm{i}$ barns tekster og tegninger, spør vi samtidig etter hvilke av samfunnets verdier - slik de kommer til uttrykk bl.a. i skolens formålsparagraf - de identifiserte seg med i dagene etter terroren. Vi vil sette søkelyset på de viktigste av disse i denne artikkelen.

\section{《Tekster og tegninger»3}

Vi bruker begrepene tekst/verbal tekst og tegning når vi omtaler barns ytringer. Dette er ikke en selvsagt begrepsbruk. Innenfor semiotisk tradisjon forstås både verbale, skriftlige uttrykk og visuelle, billedlige uttrykk som tekst. Dette gjøres bl.a. fordi barns ytringer - og andre ytringer ofte kombinerer elementer som ikke alltid kan kategoriseres som enten tekst eller bilde, men som reflekterer variasjonen og bland-ingen av grafiske ressurser som forfattere kan velge å bruke (Coppock, 2001). Det denne begrepsbruken reflekterer, er at de som ytrer seg, kan ta i bruk ulike kommunikasjonssystemer når de uttrykker seg. Den får også fram at både skriftlige, verbale uttrykk og billedlige uttrykk er meningsbærende uttrykksformer, og at vi står overfor en helhetlig ytring selv om den består av ulike grafiske uttrykk. Det som ikke fanges like godt opp av en slik begrepsbruk, er at en multimodal tekst til tross for helheten består av ulike uttrykksformer hentet fra kommunikasjonssystemer med ulik grammatikk (Kress \& Leeuwen, 2000). Slik vi ser det, degraderes den billedlige uttrykksformen langt på veg til å bli «et underbruk» av den skriftlige, verbale uttrykksformen når en tegning eller en multimodal ytring kun omtales som tekst. Med fare for å skille mer mellom verbal tekst og tegning enn barns ytringer fra minnematerialet egentlig gir dekning for, vil vi i det følgende derfor bruke begrepet tekst eller skriftlig verbal-tekst om barns skriftlige, verbale uttrykk og begrepet tegning eller bilde om deres billedlige, visuelle ytringer.

\section{Kress og van Leeuwens gramma- tikk for vestlig visuell design}

Den delen av minnematerialet som vi vil presentere her, består av tekster og tegninger eller en kombinasjon av disse to modalitetene. Siden vi er opptatt av hva dette

3 Dette avsnittet bygger på avsnittet Tekst i (Lied, 2004). 
materialet sier om barns og unges dialoger med verdier, kan Kress og van Leeuwens grammatikk for vestlig visuell design være én tilnærmingsmåte til arbeidet vårt med disse ytringene. Kress og van Leeuwen studerer nemlig hvordan visuelle ytringer kommuniserer mening. De presiserer at grammatikken for visuell design som de presenterer, er en grammatikk som består av elementer og regler som er typiske for vestlig kulturs visuelle kommunikasjon (Kress \& Van Leeuwen, 2006). Når en ytrer seg, vil en alltid være i dialog med de uttrykksformer som er vanlige i det samfunnet en er en del av og kommuniserer inn i. Det er imidlertid viktig å understreke at dette ikke behøver bety at den som ytrer seg med bakgrunn i vestlig visuell grammatikk, alltid følger denne i detalj. Både når en snakker og når en ytrer seg visuelt, vil en kunne komme til å bryte grammatikkens strenge regler.

Kress og van Leeuwen skjelner mellom narrative og konseptuelle representasjoner i visuell design. Narrative representasjoner framstiller handling og peker på hva som foregår i bildet eller presentasjonen. Aktører og pekere er viktige i denne forbindelse. Pekerne framhever aktørene i bildet, knytter dem sammen og retter oppmerksomheten mot det som skjer i bildet. Både piler, linjer, blikk, snakkebobler og andre elementer i bildet kan fungere som pekere. Konseptuelle representasjoner viser sosiale konstruksjoner i bildet: Begreper og ideer er med på å understreke hva som er sentralt og viktig, og størrelse, plassering, detaljer, farge og symboler kan si noe om hva de ulike elementene i det visuelle uttrykket betyr eller er.

Ifølge Kress og van Leeuwen må en lese fra toppen og nedover og fra venstre mot høyre i møte med vestlig visuell design. De beskriver dermed en leseretning i møte med denne type design som går fra topp til bunn og fra venstre til høyre, og følger med det den leseretningen som er i bruk innenfor vestlig skriftkultur. Ifølge deres grammatikk for vestlig visuell design, inneholder den øverste delen av en komposisjon «the Ideal», ofte det vi ser som komposisjonens essens, dens mest fremtredende informasjon eller dens viktigste tema. Denne delen utgjør forgrunn i komposisjonens budskap. Den nederste delen, «the Real», presenterer mer detaljert og praktisk informasjon. Disse to delene utdyper hverandre, men den $\emptyset$ verste delen spiller alltid den ledende rollen. Den venstre siden av en komposisjon inneholder «the Given», det som det forventes at leseren allerede skal kjenne til som en del av kulturen, mens høyre side, «the New», inneholder det nye eller det som ikke er kjent eller akseptert som selvsagt - komposisjonens budskap.

Vårt utgangspunkt er altså at budskapet i verbaltekstene og tegningene fra barn og unge etter 22. juli kommer bl.a. fram gjennom ytringenes design. Fordi Kress og van Leeuwens grammatikk for vestlig, visuell design har visuelle ytringers meningskommunikasjon i fokus, kan arbeid med dette designet som analyseredskap hjelpe til med å løfte fram de verdiene som barn og unge presenterte som sentrale i tekstene og tegningene sine etter 22. juliterroren. Dette arbeidet vil også kunne antyde om noen av formålsparagrafens sentrale verdier hører til blant disse.

\section{VERDIER SOM BARN LØFTER FRAM SOM} SENTRALE

Lied har studert alle ytringer fra den delen av det digitaliserte materialet fra 
Domkirkeplassen i Oslo og fra Utvika som Riksarkivet har kalt «hilsener/tegninger med og uten tekst», og som utgjør i alt ca. 2700 ytringer fra voksne, ungdommer og barn. De verdiene som er de mest dominerende i denne delen av minnematerialet, er kjærlighet (1219 eller ca $46 \%$ ) og samhold (883 eller ca $33 \%$ ). Som uttrykk for kjœrlighet regnes verbale tekstuttrykk for kjærlighet samt tegninger av hjerter, klemmer etc. Som uttrykk for samhold regnes verbale uttrykk for støtte, fellesskap og samhold med mennesker og Norge som land, og tegninger av mennesker som holder hverandre i hendene, regnbue (fordi regnbuen er et tradisjonelt symbol på enhet i mangfold) og norske flagg. ${ }^{4}$ Som vi allerede har understreket, vil vi imidlertid kun trekke fram ytringer fra barn i denne artikkelen. Vi starter med tekster og tegninger der verdiene kjærlighet og samhold er i fokus.

\section{Kjærlighet og samhold}

I flere av ytringene kombinerer barn de to verdiene kjærlighet og samhold, slik den følgende ytringen, laget av ei 8-årig jente, viser:

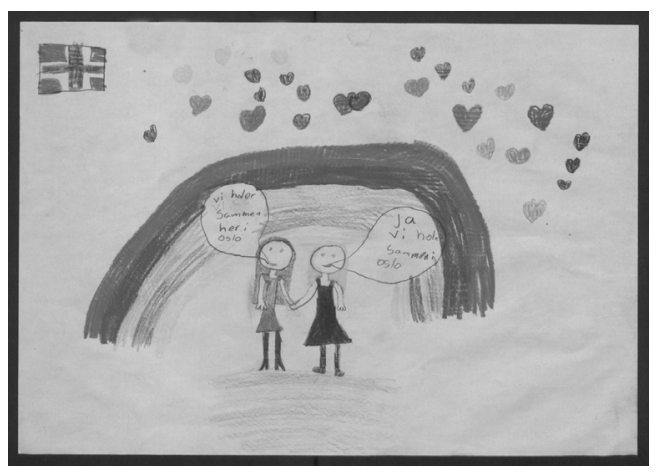

Fig. 1 For å se bildene i farger og større, se: http://www. iko.no/forlaget/metode-og-fag/prismet-nr-03-16 $\emptyset$ verst i denne ytringen - i det Kress og van Leeuwen kaller «the Ideal» og som ifølge dem inneholder komposisjonens essens ser vi en himmel som er fylt med mangefargede hjerter og et norsk flagg. Ytringens nederste del, «the Real», der den mer detaljerte informasjonen kommer fram, viser en regnbue som omslutter to jenter, en brunhåret og en lyshåret. De holder hender der de står under regnbuen. Jenta med brunt hår sier: «Vi holder sammen her i Oslo», og den lyshårede svarer: «Ja vi holder sammen i Oslo».

Det er verdt å legge merke til at hjertene er mangefargede. Det er mulig à tolke dem kun som et barns lek med farger. Men plasseringen av hjertene like over regnbuen antyder et fellesskap mellom disse elementene: hjerter og regnbue har det til felles at de er preget av et markant fargemangfold. Både regnbuen og hjertene kan forstås som konseptuelle representasjoner: Regnbuen er et ofte brukt symbol for enhet i mangfold i vestlig tradisjon. Kjærligheten som hjertene symboliserer, er mangefargede og kan forstås som kjærlighet i møte med mangfold. Regnbuen med de to jentene under er i tillegg plassert midt i bildet like under de fargeglade hjertene. Både symbolene, deres plassering og det de to jentene sier og gjør, framhever her samhold og enhet på tvers av mangfold: Vi holder sammen i Oslo. Vi er forskjellige, men likevel holder vi sammen.

Denne tolkningen st $\emptyset$ ttes av at symbolet «barn av regnbuen» er et velkjent symbol på enhet i mangfold i Norge. Lillebjørn Nilsens sang Barn av regnbuen har blitt flittig brukt i norsk skole siden den kom i 1973, og det er sannsynlig at den er kjent av de fleste norske skolebarn. Sangen ble også

\footnotetext{
4 For en framstilling av det norske flagg som et symbol på samhold og for en nærmere redegjørelse for kategorisering, se Lied og Undseth Bakke, 2013.
} 
sunget i mange norske byer en av dagene mens rettssaken mot terroristen pågikk i 2012. Den fungerte da som en protest fra det norske folk mot Breiviks påstand om at sangen hjernevasker norske elever og er en propaganda for et flerkulturelt samfunn gjennom budskapet den har om enhet i mangfold. Samhold, mangfold og en himmel med en fargerik regnbue var altså en velkjent symbolkombinasjon i Norge både før og etter terroren 22. juli. Flere av hilsenene Lied har studert, inkluderer regnbuer, ofte sammen med symboler på kjærlighet og samhold slik som hjerter, roser, norske flagg og verbale uttrykk for enhet i mangfold.

Verdiene som jenta her løfter fram, nemlig kjærlighet, mangfold og samhold, var verdier som var $\mathrm{i}$ fokus $\mathrm{i}$ det norske samfunnet i tiden etter terrorangrepene. De var bl.a. del av sentrale verdibudskap fra ledende norske politiske representanter, massemedia og den kongelige familie i denne tiden (Haakon, 2011; Stoltenberg, 2011a, 2011b). Vi finner dem også i formålsparagrafen, der presentert som nestekjærlighet og solidaritet, likeverd og innsikt i kulturelt mangfold. Den åtte år gamle jenta gir altså i denne ytringen uttrykk for at hun støtter verdier som er sentrale $\mathrm{i}$ hennes sosiale kontekst.

\section{Overraskende og inkluderende kjærlighet}

To av de 2700 ytringene Lied har gransket, inkluderer terroristens familie og venner i det fellesskapet av kjærlighet og samhold som kom til uttrykk i tiden like etter 22. juli. En av disse var undertegnet av en gutt på sju og to jenter på 11 år. Teksten øverst på siden, komposisjonens viktigste tema og budskap, sier: «Våre tanker går til de avdøde, pårørende og Anders Breiviks familie og venner. Norge holder sammen». Samholdet som denne verbalteksten gir uttrykk for, understrekes ytterligere av tegningen som infiltrerer teksten, nemlig et kart over Norge skapt av fyrstikkmenn som holder hverandre $\mathrm{i}$ hendene. Under dette multimodale uttrykket, i den delen av komposisjonen som skal inneholde mer detaljert informasjon, ser vi to engler med glorier og vinger. Den største av dem holder et lys, den minste en rose. Teksten til venstre i ytringen - som ifølge Kress og van Leeuwen inneholder det som det forventes at leseren skal kjenne til - sier: «Dere skal aldri glemmes». Teksten på innsiden av det røde hjertet til høyre sier: «Hvil i fred». Denne rammen som tekstene gir de to englene, gjør det rimelig å tro at englene her representerer de avdøde.

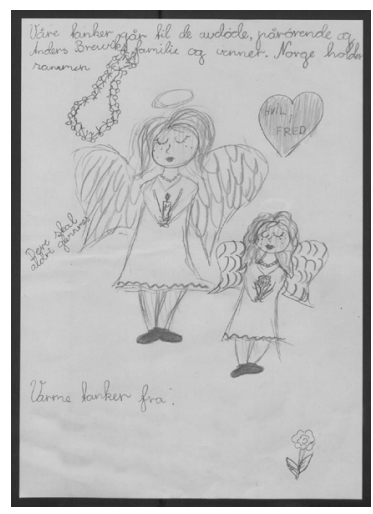

Fig. 2

Det sentrale i denne ytringen er samhold. Dette samholdet inkluderer både de avdøde og deres nærmeste, og terroristens nærmeste. Det er ikke overraskende at de første inkluderes. Det var lett å føle kjærlighet og vise medfølelse med dem som ble så hardt rammet, og minnematerialet inneholder tusenvis av uttrykk for kjærlig omsorg og sympati med ofrene og deres familier. Men 
de som har laget denne ytringen, gjør seg til talsmenn for en type kjærlighet som kan sies å være både utvidet, uventet og overraskende, nemlig noe som ligner fiendekjærlighet: De har klart å inkludere i sin medfølelse ikke bare de det var lett å elske, men også de det var lett å bebreide og vise mistillit. ${ }^{5}$ Det er kanskje en tilslutning til denne typen kjærlighet vi også kan ane i det neste avsnittet, der kjærligheten introduseres som et våpen mot ondskapen.

\section{Kjærlighet som våpen}
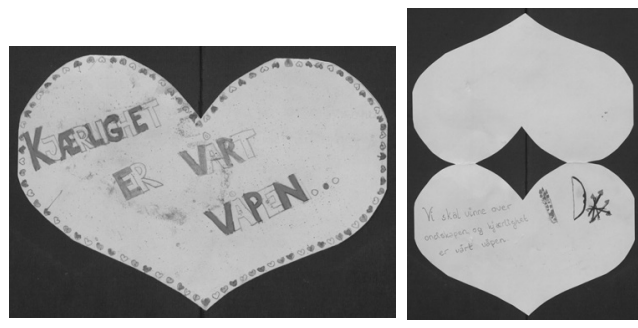

Fig. 3

Noen ytringer fra minnematerialet framhever kjærligheten som våpen mot Breiviks ideologi, eller, mer overgripende, som våpen mot det onde. Fig. 3 viser en slik ytring i form av et dobbelt, hjerteformet kort laget av to jenter, på henholdsvis åtte og 13 år. Verbalteksten midt på kortets framside sier: «Kjærlighet er vårt våpen ...». Langs hjertets ytterkant finner vi 90 små, røde, rosa og hvite hjerter. Når vi åpner hjertet, finner vi en tekst som utdyper teksten på framsiden. I venstre hjertekammer har de to jentene skrevet: «Vi skal vinne over ondskapen og kjærlighet er vårt våpen». Til høyre for denne teksten finner vi, ifølge den vestlige, visuelle grammatikken, komposisjonens budskap: en bue og et kogger med piler med hjerteformede spis- ser - kjærlighetens våpen konkretisert.

Kjærlighet og våpen blir ofte sett som motsatte kategorier. Men noen ganger smelter disse kategoriene sammen, for eksempel i Mahatma Ghandis ikke-voldsdoktrine og $\mathrm{i}$ fortellingen om den unge trollmannen Harry Potter der kjærligheten framstilles som våpenet over alle andre $\mathrm{i}$ kampen mot det onde. Vi kan også se denne kombinasjonen i lys av sentrale tekster i den kristne Bibel. Her sies det at kjærligheten er størst av alt, og det anbefales å bruke Guds ord som våpen og beskyttelse mot det onde (1. Kor 13; Ef 6). Ved å koble sammen de to tilsynelatende motstridende størrelsene kjærlighet og våpen i dette kortet, skaper de to jentene - i samsvar med fortellinger og tekster som presenterer kjærligheten som det uovervinnelige våpen - rom for en kamp som ikke er voldelig. Meldingen vi kan lese ut av dette kortet er: Vi vil ikke gi opp! Vi vil kjempe mot det onde, men vi vil gjøre det på vår måte og velge våre egne våpen - nemlig kjærlighetens!

\section{Verdier som barn løfter fram som sentrale}

Så langt har vi argumentert for at de verdier vi finner at barn oftest løfter fram i de tekstene og tegningene de la ned på Domkirkeplassen i Oslo og i Utvika etter 22. juli, er kjærlighet og samhold. Disse verdibaserte tekstene og tegningene ble laget $\mathrm{i}$ den kommunikasjonssfæren som Norge på den tiden ytringene ble skrevet, utgjorde. Verdiene som kom til uttrykk i det barna skrev og tegnet, finner vi også i taler fra ledende politiske og nasjonale representanter, i massemedia og sosiale media, i

5 Se også Kjetil Stormark som refererer til det han kaller «de unike meldingene» som ble sendt til Breiviks e-post, hvor noen

skriver at de vil be for overgriperen (Stormark, 2012, s. 262). 
rosetog og spontane minnesteder. Barnas ytringer kan altså synes å speile noen av samfunnets tradisjonelle verdier og måten disse ble kommunisert på i denne spesielle tiden, verdier som også formålsparagrafen fremmer.

Men bildet av kjærlighet og samhold er ikke det eneste bildet fra denne tiden. Barns tekster og tegninger indikerer også at noen av samfunnets sentrale verdier var truet eller under press. Det doble hjertekortet som presenterer kjærligheten som våpen mot det onde, er en slik indikasjon. For en kan spørre: Hvilken ondskap er det kjærligheten skal beseire? Hva er det som kalles ondskap? Hva sier barnas tekster og tegninger om hvilke verdier som er truet eller under press av det onde? Dette er tema for artikkelens neste hovedavsnitt.

\section{Truede Verdier og Verdier UNDER PRESS}

Som allerede nevnt, blir liv og helse ofte framstilt som grunnleggende verdier (se f.eks. Barbosa da Silva, 2006; Heiene \& Thorbjørnsen, 2001; Hummelvoll, 2014). Disse verdiene var også i fokus da professor Jan Olav Henriksen og psykolog Gry Stålsett ble bedt om å definere ondskap i lys av terrorangrepene i 2011. Begge understreket viljen til å påføre andre skade og smerte og det å ødelegge andres liv med vitende og vilje som sentrale deler av dette begrepet (Helmikstøl, 2012; se også Vetlesen, 2014). Breiviks terror som en trussel mot livet er også et sentralt aspekt i barns ytringer etter 22.juli. Mange av disse ytringene uttrykker sinne mot Breivik: Noen refser ham og kaller ham slem, andre gjør narr av ham, og andre igjen uttrykker glede over å se ham i fengsel. Bare to av de ytringene Lied har sett på, ønsker ham død.

\section{Verdien liv truet av Breiviks handlinger}

Både bombingen av regjeringskvartalet og skytingen på Utøya var i fokus når barn uttrykte sinne og frykt i etterkant av terroren.

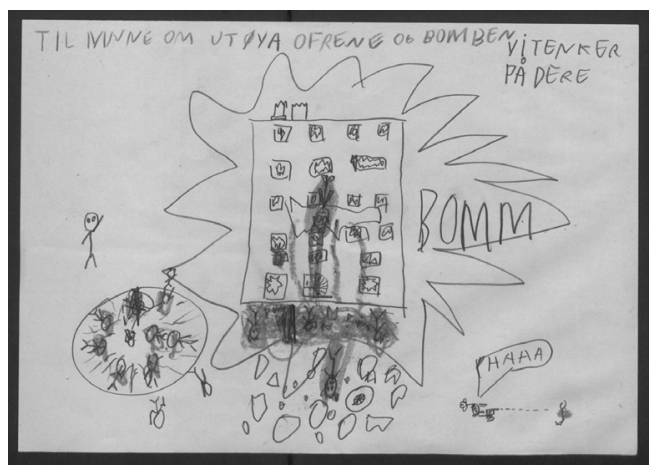

Fig. 4

Fig. 4 er laget av en ni år gammel gutt. $\emptyset$ verst i denne ytringen, der vi finner komposisjonens viktigste tema, finner vi en verbaltekst som sier: «Til minne om Utøyaofrene og bomben. Vi tenker på dere. Hilsen NN 9 år». Under denne teksten har gutten gitt oss mer detaljert informasjon ved å tegne det som hendte. Eksplosjonen $\mathrm{i}$ regjeringsbygningen er plassert i sentrum. Vi ser knuste vinduer. Noen av disse er farget røde. Fargen antyder antakelig blod. Foran bygningen har gutten plassert døde og sårede som også er dekket med blod. Han har skrevet BOMM med store bokstaver inne $\mathrm{i}$ en «eksplosjonsstjerne», noe som understreker informasjonen i verbalteksten ytterligere. I ytringens venstre side, der vi skal forvente å finne det vi allerede kjenner til, ser vi en fyrstikkmann som står med løftet arm. Jubler han, eller $\emptyset$ nsker han bare å peke på det som skjer? Under denne mannen ser vi en sirkel som omkranser mennesker dekket av blod. Dette er trolig Utøya og ofrene her. Utenfor øya ser vi mennes- 
ker i sjøen. I ytringens nedre, høgre hjørne, der vi kan forvente å finne det som ikke er så selvsagt eller komposisjonens budskap, ser vi en mann med et skytevåpen i hånden. Det kommer flere prikker ut av våpenets munning, trolig kuler. Disse treffer et menneske som ligger på marka, dekket av blod. «HAAA» står det i snakkeboblen som kommer fra den skytende mannen, noe som trolig markerer latter.

Med andre ord: Den ni år gamle guttens budskap er at skytingen på Utøya er gjort med fryd av en leende terrorist. Hvis fyrstikkmannen på venstre side av den bombede bygningen jubler, har gutten antydet at hendelsene $\mathrm{i}$ regjeringskvartalet er gjort med en viss fryd, også. Men stemningen i guttens ytring er ikke frydefull. Verbalteksten sammen med tegningen viser at dette er en multimodal ytring som framstiller to grusomme hendelser: Breivik bomber og skyter og gjør begge deler med lattermild fryd. Gutten har her kontrastert Breiviks fryd over å drepe med handlingens gru, og har brukt denne kontrasten til å understreke sin egen avsky for ondskapen overgriperen her viser. Dermed viser han at livet som verdi er truet av Breiviks handlinger. Med andre ord, han støtter sin sosiale kontekst i forståelsen av livet som grunnleggende verdi. Denne forståelsen leder ham i sin tur til å gå inn i en kritisk dialog med Breiviks handlinger: Gjerningene hans ses som onde fordi de truer verdien liv.

\section{Breivik latterliggjøres}

I noen ytringer blir kritikken av Breiviks handlinger sammen med tilslutningen til verdien liv som en grunnleggende verdi, mer renskåret. Fig. 5, som går over tre sider, er en av disse.
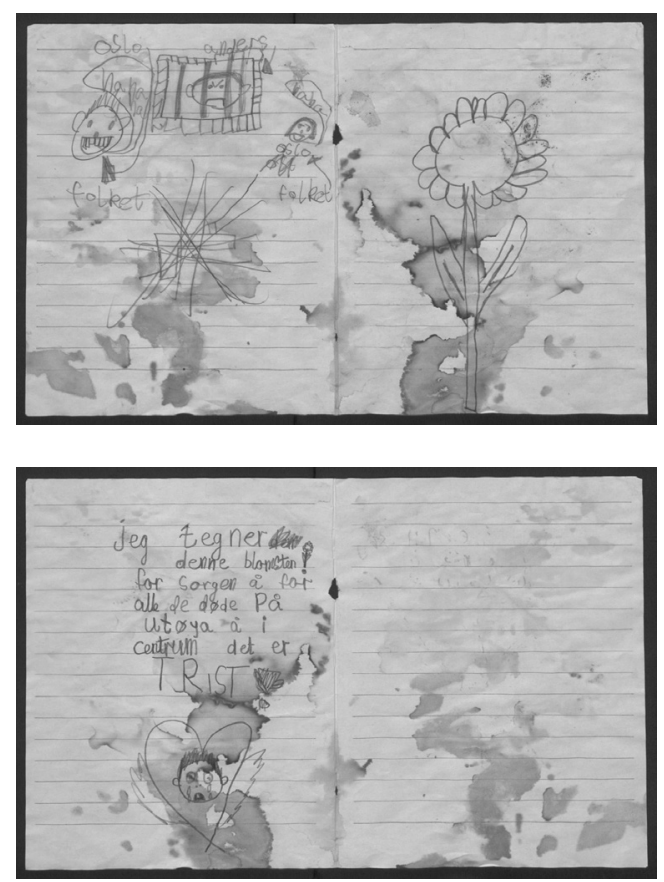

Fig. 5

$\emptyset$ verst på ytringens første side ser vi et sint ansikt bak et tilgitret vindu. Det står «Anders» over vinduet. En pil peker mot mannen bak gitteret. Dette gjør at vi forstår at det er terroristen vi ser. En mann og en dame som representanter for «Oslofolket» er tegnet utenfor på begge sider av vinduet. De ler. Under denne multimodale komposisjonen utdypes informasjonen vi får фverst på siden: hakekorset er tegnet med et solid kryss over. På ytringens andre side er det tegnet en blomst, mens verbalteksten $\emptyset$ verst på tredje side sier: «Jeg tegner denne blomsten for sorgen å for alle de døde På Utøya å i sentrum det er TRIST! » Under denne teksten understrekes det triste av et grătende ansikt inni et hjerte med vinger.

Denne ytringen gjør narr av terroristen ved å putte ham $\mathrm{i}$ fengsel og ved å vise at Oslofolket utenfor ler av ham. Bakhtin presenterer latter som et våpen som deak- 
tiverer det farlige og beskytter mot det truende. Latter er vanlige menneskers våpen mot overmakten: «One plays with the frightening and laughs at it. The frightening is reduced to a scarecrow» (Bakhtin, 2003, s. 69). Men ifølge Bakhtin er latter også en måte å distansere seg fra nåtiden på, gjøre den til fortid, og slik forhindre den fra å bli en del av framtiden. Med andre ord: Ved å le av Breivik, nøytraliserer barnet som har laget denne ytringen, Breivik, plasserer ham i fortiden og ekskluderer ham fra å påvirke framtiden. Dette gjør barnet gjennom en kritisk vurdering av Breivik og hans terrorhandlinger og med tilslutning til livet som en verdi - en verdi som er truet av ham. Leser vi denne ytringen fra venstre mot høyre i tråd med tradisjonell vestlig leseretning, ser vi at grunnen til at barnet er glad for å se at Breivik blir latterliggjort mens han sitter i fengsel, er «alle de døde» som mistet livet i terroren.

Flere barn uttrykker altså sinne over terroristens handlinger, de skjenner på ham eller gjør narr av ham, samtidig som de uttrykker omsorg og kjærlighet for ofrene og deres familie og venner. Noen få tekster og tegninger fra minnematerialet ser imidlertid ut til å ta bebreidelsen et steg videre: De synes å frata Breivik hans menneskeverd mens de latterliggjør ham. Den neste ytringen, fig. 6 , kan stå som et eksempel på en slik dehumanisering.

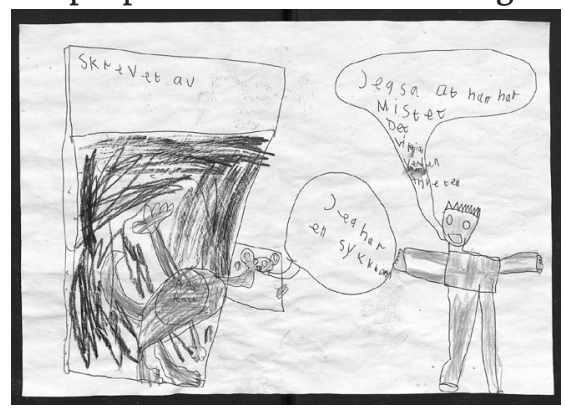

Fig. 6
Til venstre i denne multimodale ytringen laget av en gutt på åtte år, ser vi et dyr som oppholder seg i et svart rom, antakelig et fengsel eller et bur, for vi kan se en dør eller en luke med en nøkkel i, tegnet inn bak dyrets hode. Dyret er en ape. Det vet vi fordi det har en lapp med ordet «apekatt» på brystet. I snakkeboblen som kommer fra apens munn, står det: «Jeg har en sykdom». Utenfor buret eller fengselet og til høyre i komposisjonen står en gutt kledd i blå bukse og genser som minner om det norske flagget. Han peker på dyret og sier: «Jeg sa at han har Mistet Det vigtigste vi har - friheten $\gg$.

Det er trolig at dyret i buret her er ment å være Breivik, siden det er til venstre vi ifølge Kress og van Leeuwen skal finne «the Given», det kjente: Breivik må være et dyr når han kunne gjøre det han gjorde! I tiden etter 22. juli var spørsmålet om Breiviks psykiske helse et tema som ble diskutert $\mathrm{i}$ flere medier. Noen mente han var utilregnelig, andre ikke. Det som imidlertid ble holdt fram som det viktigste på tvers av posisjon i denne debatten, var at samfunnet måtte bli beskyttet fra ham ved at han ble sperret inne. Det kan være at den åtteårige gutten har vært kjent med denne debatten og valgt side, når han her latterliggjør Breivik og framstiller ham som en syk og innesperret apekatt. Ved å tegne gutten utenfor apeburet med klær i norske flaggfarger, er det mulig at tegneren vil si at han representerer det norske folk som står og peker på Breivik og er glad for at han er i fengsel. Siden gutten er plassert på høyre side i komposisjonen, er det sannsynlig at det er gleden over at Breivik er fratatt friheten, som er ytringens budskap. I så fall finner vi her i fig. 6 noe av det samme temaet som i fig. 5: Breivik er innesperret og latterliggjøres. 
Terroristen er framstilt som en apekatt. Det er et ikke uvanlig litterært grep å framstille mennesker som dyr i bildebøker for barn, når en vil diskutere forhold mellom mennesker. Det er mulig det er et slikt litterært virkemiddel vi ser anvendt her. Men det å framstille Breivik som en apekatt, kan også tolkes som et dehumaniserende grep: Ved å framstille ham slik, ekskluderes terroristen både fra fellesskapet mellom mennesker og fra respekten som ethvert menneske kan kreve i kraft av å være menneske. Han fratas da, i denne ytringen, ikke bare friheten, men også sitt menneskeverd. Kritikken som den åtteårige gutten her konfronterer Breivik og hans terrorhandlinger med, har altså samtidig satt verdien menneskeverd under press. I Kvesets og Lieds artikkel «Arbeid med verdier» $\mathrm{i}$ inneværende nummer av Prismet, presenteres en ytring fra ei jente som både slutter seg til forståelsen av verdien liv som grunnleggende, samtidig som hun kritiserer Breiviks handlinger. I sin presentasjon av kritikken mot Breivik fratar hun ham hans menneskeverd gjennom å gjøre ham ansiktsløs, kalle ham en djevel og ønske ham død. Hun gjør altså noe av det samme som gutten som har laget fig. 6 , gjør, men hun går et skritt lenger: I sin argumentasjon for ofrenes rett til liv truer hun både Breiviks menneskeverd og hans rett til liv, en rett han - som menneske - har. Med andre ord: Kampen for menneskets iboende rett til liv fører altså hos denne jenta til at den samme retten settes under press eller trues.

I det norske juridiske systemet er ikke dødsstraff et alternativ. Her er respekten for menneskeverdet og for livet som en udiskutabel menneskerett, sammenkoblet. Selv om Breivik ble stilt for retten for å ha drept 77 personer og såret mange alvorlig, ga norsk lov ham det som her er betraktet som en selvsagt del av det å være menneske, nemlig retten til liv. Derfor ble han ikke henrettet. Men han fikk norsk lovs strengeste straff: forvaring.

Sinne og avsky er naturlige reaksjoner stilt overfor terrorhandlinger som de Breivik gjennomførte. Og, som Bakhtin peker på, så kan latter være et kraftfullt våpen for de undertrykte i møte med overmakten. Latter og latterliggjøring kan ses som nærliggende strategier. Begge kan brukes som våpen mot undertrykking, fordi de er med på å redusere det skremmende og gjøre det til «a scarecrow» (Bakhtin, 2003, s. 69). I tiden etter 22. juli kan det å gjøre Breivik til et fugleskremsel ved å plassere ham bak tilgitrede vinduer, avbilde ham som en apekatt eller gjøre ham til en ansiktsløs djevel som fortjener å dø, ha blitt opplevd som en legitim reaksjon. Ungdommene som han drepte på Utøya, hadde nemlig ingen våpen. De var forsvarsløse i møte med ham og hans tunge bevæpning. Noen barn kan derfor ha opplevd ham som en undertrykkende makt som fortjente å bli ekskludert fra samholdet og kjærligheten som preget det norske samfunnet dagene etter terroren, og som hadde godt av å bli både latterliggjort og dehumanisert. Likevel aktualiserer disse ytringene viktige spørsmål: Har en massemorder menneskeverd? Er ofrenes menneskeverd i fare dersom morderen behandles som et medmenneske? Hva skjer når selve kampen for grunnleggende verdier - som liv og menneskeverd - setter de samme verdiene under press? Det er verdt å merke seg at når formålsparagrafen skal konkretisere det Stortinget har vedtatt er de grunnleggende verdiene i kristen og humanistisk tradisjon 
som opplæringen i norsk skole skal bygge på, så er menneskeverdet den første verdien som løftes fram.

\section{Avsluttende diskusjon}

Mange barn som skrev og tegnet i tiden etter terroren 22. juli 2011, ser ut til å ha sluttet seg til verdier som er sentrale i det norske samfunnet og som bl.a. kommer til uttrykk i formålsparagrafen. Disse verdiene manifesterte seg både gjennom sosiale medier og massemedier og gjennom ulike offentlige handlinger og markeringer.

Norsk skole er den offentlige institusjonen som har som oppdrag å formidle til den oppvoksende slekt kunnskap og holdninger som samfunnet finner så verdifulle at alle dets innbyggere skal kjenne til dem. Norsk skoles formålsparagraf, gjeldende fra januar 2009, skisserer en verdibasert plattform for skole og utdanning (Stub $\emptyset$, 2012). Noen av de sentrale verdiene som denne paragrafen løfter fram, er menneskeverd, nestekjærlighet, likeverd og solidaritet (Kunnskapsdepartementet, 2008a, § 1-1). Som vi har vist i denne artikkelen, støttet barn verdier som disse i sine tekster og tegninger etter 22. juli, selv om disse ytringene var skrevet og tegnet i sommerferien og ikke i skoletiden. Med andre ord er disse verdiene til en viss grad internalisert hos barna som skrev disse ytringene. Vi vil derfor påstå at det norske samfunnet - som skolen er en del av - har lykkes i å kommunisere i det minste en del av sin verdiplattform til sine barn.

Men dette er ikke hele det bildet som minnematerialet etter 22. juli viser oss. Barns tekster og tegninger fra Domkirkeplassen i Oslo og Utvika viser at sentrale verdier som liv og menneskeverd et stykke på veg var truet eller under press i dagene etter terrorangrepene: Breivik ble, i noen av ytringene, latterliggjort, dehumanisert og $\emptyset$ nsket livet av. Så til tross for den overveldende støtten til verdier som kjærlighet og samhold, liv og respekt for menneskeverdet som vi finner i minnematerialets tekster og tegninger fra barn, gjorde selve kampen for disse verdiene at de til tider samtidig ble satt under press.

Men disse verdiene ble også satt under press på en mer konkret måte i dagene etter terroren. I de første timene etter at bombingen av regjeringskvartalet ble kjent, ble det antydet - både i media og på folkemunne - at det var muslimske ekstremister som hadde utført bombingen. Dette førte til at norske muslimer - også norske barn - møtte denne mistanken i form av verbal mobbing i butikken, på gata og på T-banen (se f.eks. Murtnes, 2011; Vikås, 2011; Zondag, 2011). Fig. 7 nedenfor setter søkelyset på dette. Ytringen er skrevet av et muslimsk innvandrerbarn som ennå ikke er helt trygg i norsk språk. Barnet skriver: «Til Alle sammen i hele verden. Hei. Jeg veldig lei meg med det som skjedde i Oslo sentrum og i Utøya. Han som gjore det liker ikke muslim. Men jeg er muslim og er normal. Vi er snille. Ha det!!»

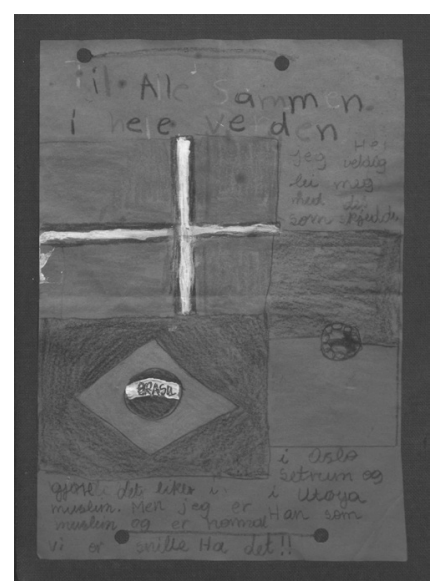

Fig. 7 
At et barn som bodde i Norge i dagene etter terrorangrepene fant det nødvendig å skrive til hele verden at hun/han, som muslim, er normal og snill, skulle - slik jeg ser det være et tydelig signal til norsk skole om å sette formålsparagrafens verdier i fokus i undervisningen, bl.a. respekt for menneskeverdet, nestekjærlighet og respekt for ulike religioner og livssyn. Derfor vil vi avslutte med et forslag: Flere av tekstene og tegningene fra spontane minnesteder etter angrepene 22. juli var skrevet av barn og unge som viste sin støtte til verdier som også er sentrale i formålsparagrafen. I disse ytringene kan lærere derfor finne både aktualisering for og eksempler på uttrykk som støtter verdier som formålsparagrafen sier skal være sentrale i undervisningen i norsk skole, og eksempler på ytringer der disse verdiene er under press. Barns og unges tekster og tegninger fra minnematerialet kan lette elevers forståelse av sentrale verdier, fordi ytringene er laget av personer på samme alder som elevene selv og derfor er skrevet i et språk som inneholder symboler, regler og forhandlingsrutiner som elevene er kjent med fra dagliglivet sitt, f.eks. tegning og skriving på skolen (Afdal, 2007, 2010; Lied, 2008). Derfor foreslår vi at lærere inkluderer noen av disse ytringene i læremidlene de bruker når temaet verdier står på timeplanen. I dette nummeret av Prismet finner en to artikler som gir forslag til hvordan dette kan gjøres.

\section{LitTERATUR}

Heiene, G. \& Thorbjørnsen, S. O. (2001). Fellesskap og ansvar : innføring i kristen etikk ([2. utg.]. utg.). Oslo: Universitetsforl. Helmikstøl, Ø. (2012). På tide å snakke om ondskap. Tidsskrift for Norsk Psykologforening, 9(5), 471-479.
Hummelvoll, J. K. (2014). Helt - ikke stykkevis og delt. Psykiatrisk sykepleie og psykisk helse (7th utg.). Oslo: Gyldendal Akademisk.

Kress, G. \& Leeuwen, T. v. (2000). Reading images : the grammar of visual design. London: Routledge.

Kress, G. \& Van Leeuwen, T. (2006). Reading images : the grammar of visual design. London: Routledge.

Kunnskapsdepartementet. (2008a). Lov om grunnskolen og den videregåande opplæringa (Opplæringslova). Lokalisert på http://www.lovdata.no/all/tl-19980717061-001.html

Kunnskapsdepartementet. (2008b). regjeringen.no/nb/dep/kd/dok/tidsskrift nyhetsbrev/forsiden-kd-aktuelt2/kdktuelt-nr-1008/grunnopplaring/nyeformalsparagrafer-for-skole-og-barne. html.

Lied, S. (2004). Elever og livstolkingspluralitet $i \mathrm{KRL}$-faget : mellomtrinnselever $i$ møte med fortellinger fra ulike religioner og livssyn. Elverum: Høgskolen i Hedmark.

Lied, S. (2008). Forskningsfellesskap med aktivitetsteoretisk profil. Prismet, 3/2008, årgang 59, 171-182.

Lied, S. (2012). Elever i videregående skole i møte med et etisk dilemma. I S. Lied \& C. Osbeck (Red.), Religionsdidaktisk arbeid pågår! Religionsdidaktikk i Hamar og Karlstad (s. 165-190). Vallset: Oplandske Bokforlag. Lied, S. \& Lödén, H. (2014). Minnematerialet etter 22. juli: En kilde til informasjon om det norske samfunnet. Arkivmagasinet, 29-32.

Lied, S. \& Undseth Bakke, S. (2013). Canon and archive in messages from Oslo Cathedral Square in the aftermath of July 22nd 2011. Nordidactica(1), 34-56.

Løken, H. (2012). Det vurderende mennesket og den moralske virkelighet. 
Charles Taylor om autentisitetskultur og sterke vurderinger. I S. Lied \& C. Osbeck (Red.), Religionsdidaktisk arbeid pågår! Religionsdidaktikk $i$ Hamar og Karlstad. Vallset: Oplandske Bokforlag.

Murtnes, S. (2011). Kadra: Muslimer ble jaget nedover gatene, http://www.vg.no/ nyheter/innenriks/terrorangrepet 22-juli-politikk-og-samfunn/kadramuslimer-ble-jaget-nedover-gatene/ a/10088913/. Lokalisert på http://www. vg.no/nyheter/innenriks/terrorangrepet-22-juli-politikk-og-samfunn/ kadra-muslimer-ble-jaget-nedovergatene/a/10088913/

Norli, S. \& Gausdal, O. (2013). 22. juli-arkivene i Riksarkivet. [arkiv]magasinet(1/13), 38-41.

Stoltenberg, J. (2011a). Sjokkerende og feigt. Tale holdt 22. juli 2011. Lokalisert på http://www.regjeringen.no/nb/dep/smk/ aktuelt/taler_og_artikler/statsministeren/statsminister_jens_stoltenberg/2011/ sjokkerende-og-feigt.html id= 673127

Stoltenberg, J. (2011b). Tale ved Statsminister Jens Stoltenberg i Oslo Domkirke 24.07.2011. Lokalisert på http://www. regjeringen.no/nb/dep/smk/aktuelt/ taler_og_artikler/statsministeren/statsminister_jens_stoltenberg/2011/taleved-statsminister-jens-stoltenberg- . html?id=651789

Stormark, K. (2011). Da terroren rammet Norge: 189 minutter som rystet verden. Oslo: Kagge.

Stormark, K. (2012). Massemorderens private $e$-poster. Oslo: Spartacus.
Stubø, I. (2012). Den norske grunnskolens formålsparagraf. Verdietikk i moralfilosofisk lys. I S. Lied \& C. Osbeck (Red.), Religionsdidaktisk arbeid pågår! Religionsdidaktikk i Hamar og Karlstad (s. 79-108). Vallset: Oplandske Bokforlag.

Säljö, R. (2006). Lœring og kulturelle redskaper: om lcereprosesser og den kollektive hukommelsen. Oslo: Cappelen akademisk forl.

Taylor, C. (1985). Human agency and language. Cambridge: Cambridge University Press.

Taylor, C. (1989). Sources of the self: the making of the modern identity. Cambridge: Cambridge University Press.

Vetlesen, A. J. (2014). Studier i ondskap. Oslo: Universitetsforlaget.

Vikås, M., med flere. (2011). Oppfordret hijabkledde jenter om å holde seg innendørs, http://www.vg.no/nyheter/innenriks/ terrorangrepet-22-juli-politikk-ogsamfunn/oppfordret-hijabkledde-jenterom-aa-holde-seg-innendoers/a/10088956/. Lokalisert på

http://www.vg.no/nyheter/innenriks/terrorangrepet-22-juli-politikk-og-samfunn/ oppfordret-hijabkledde-jenter-om-aaholde-seg-innendoers/a/10088956/

Vygotskij, L. S. (2001). Tenkning og tale. Oslo: Gyldendal Akademisk.

Zondag, M. H. W. (2011). Muslimer ble hetset etter terroren, http://www.nrk.no/ norge/meldinger-om-muslim-hets-ioslo-1.7723535. Lokalisert på http://www. nrk.no/norge/meldinger-om-muslimhets-i-oslo-1.7723535 